\title{
Generation $Z$ consumer's preferences for online food ordering application: a study of gofood and grabfood
}

\author{
Heri Akhmadi ${ }^{*}$ and Afif Rasyid Alfathah, Susanawati \\ Department of Agribusiness, Universitas Muhammadiyah Yogyakarta, Indonesia
}

\begin{abstract}
Online food ordering applications have become widely used recently. Its popularity is getting higher, especially among Generation Z, which is known to be the most familiar generation with information technology applications. This study aims to examine the preferences of Generation $\mathrm{Z}$ consumers and the most considered factors in purchasing food product using Gofood and Grabfood online food ordering applications. An online survey of 100 generation $\mathrm{Z}$ respondents was carried out through the google form application. Descriptive analysis, Ttest and one-way ANOVA were used to find out the most preferred online food ordering application and the most considered factors in purchasing food products using Gofood and Grabfood. The results showed that Gofood is the most preferred application by Generation Z. Furthermore, trust is the most considered factor in using Gofood application while practicality, promotion and trust are the major factors of Grabfood consumers preferences.
\end{abstract}

\section{Introduction}

Information technology has a great impact on human life. One sector that has benefited significantly from information technology is trade. In trading activities, information technology allows sellers and buyers to exchange information, increase efficiency and reduce transaction costs [1]. Information technology also makes it possible to get product and price information in real time in a fast time, making it easier for consumers and traders to make decisions.

E-commerce is an application of information technology in trade sector that allows buying and selling of goods and services through digital platforms [2]. The development of e-commerce in Indonesia shows an increasing trend from year to year even during the Covid-19 pandemic. A study reported that in 2020 the value of trade through e-commerce in Indonesia reached $20 \%$ of the total retail market or worth 32.2 billion USD. This number increased rapidly from only $2 \%$ in 2006 or worth 2.7 billion USD [3].

There are various e-commerce platforms used in business today, ranging from websites, social media business [4] and other internet-based applications for commerce. Among the e-commerce applications that are growing quite rapidly in Indonesia today are Gojek and

\footnotetext{
* Corresponding author: heriakhmadi@umy.ac.id
} 
Grab. This e-commerce was originally an online-based transportation service that could be accessed via a smartphone. As a business development, Gojek launched the Gofood food delivery service in 2015 followed by Grab with Grabfood in 2018 [5].

Gojek as the main brand of Gofood has 142 million users and 400 thousand partners spread across 370 cities in Indonesia in 2018. While, Grab has reportedly been downloaded 144 million times and has partners in 178 cities in Indonesia [6]. The total value of the food delivery service business in Indonesia in 2020 was USD 3.7 billion, which GrabFood dominated $53 \%$ of market share (USD 1.96 billion) while Gofood was able to capture a market of $47 \%$ or USD 1.74 billion [5]. Gofood and GrabFood are still the main players in the online food delivery business in Indonesia, although currently several e-commerce platforms are also launching similar services such as ShopeeFood from Shopee and Tokopedia Nyam from Tokopedia [7].

Ease of service, convenience of use [8] and plenty of choices are some of the reasons why the consumers choose online food ordering service platforms such as Gofood and GrabFood, especially generation $Z$ consumers. Generation $Z$ is known to be advanced in using technology [9], which directly influence their information seeking and shopping behavior. One of them is their behavior in using online food delivery service applications in buying processed food products. Previous studies have shown that Generation $\mathrm{Z}$ is the main driver of internet-based services such as online shopping [10], e-wallet [11] and other internet-based product services [12].

Demographically, Generation Z or the so-called post-millennial generation [13] is a generation born between 1995-2011 [14] or in other literature it is called born between five years before and after 2000 [15]. Based on data from the Indonesian Internet Service Providers Association (APJII), the majority of Generation Z (82\%) are active Internet users in Indonesia [16]. The results of the 2020 national census of Indonesia also state that, compared to other generations, Generation $\mathrm{Z}$ is the largest generation in Indonesia, accounting for a proportion of $27.94 \%$ of the total 270.2 million Indonesian population in 2020 [17].

Previous research on consumer preferences for purchasing food products through online platform has been widely carried out. However, study on Generation Z consumers preferences towards messaging application services between Gofood and GrabFood has not been found. Previous research has focused more on consumer purchase behavior in general (not Generation Z) both Gofood and GrabFood [18], Gofood consumer engagement [19], and on the effect of social media advertising on Gofood consumers' buying interest [20].

Based on data and previous explanation, along with the increasing use of online food delivery service applications, especially the two big players in Indonesia, Gofood and GrabFood, it is interesting to examine the extent of the Generation $\mathrm{Z}$ consumer behavior in using these two applications in online food ordering services. Therefore, this study aims to examine the preferences of Generation $\mathrm{Z}$ consumers and the most considered factors in purchasing food products using Gofood and Grabfood online food delivery applications.

\section{Methodology}

Respondents of this study were Generation $\mathrm{Z}$ consumers both from online food delivery applications of Gofood and GrabFood. Universitas Muhammadiyah Yogyakarta (UMY) students as one of the largest private universities in Yogyakarta, were chosen as representatives of Generation $Z$ consumers.

Primary data from respondents was obtained by distributing questionnaires using Google form service. There are 100 Generation $\mathrm{Z}$ consumers who responded and met the requirements to become respondents. Primary data obtained including consumer profiles, 
namely age, gender, monthly income and data on food purchases through Gofood and GrabFood.

Generation $\mathrm{Z}$ consumer perceptions of online food delivery services of Gofood and GrabFood are measured using a 5-point Likert Scale for further analysis descriptively using the average score of each variable [21]. There are four attributes that are used to measure consumer perceptions of Gofood and GrabFood, namely practicality, tariffs, speed, trust, security and promos. Furthermore, in order to examine the food deliveri service application that is preferred by generation $\mathrm{z}$ consumers, a paired $\mathrm{T}$ test is carried out. Meanwhile, to find out which attributes are more considered by consumers, the one-way Anova test is used.

\section{Result and discussion}

\subsection{Generation Z consumer profile and food purchase behaviour of Gofood and GrabFood}

The respondents of this research are Generation $\mathrm{Z}$ consumers of Gofood and GrabFood delivery service who are students of Universitas Muhammadiyah Yogyakarta (UMY). Furthermore, a purposive and proportional sample of students was taken from each faculty at UMY. Based on the questionnaire distributed online through Google form application, there were 100 consumers who responded and met the requirements to this study.

Based on the data, profiles of respondents and their purchasing behavior are compiled. There are six consumer variables in this study namely gender, income, monthly purchases, types of purchased food, product prices and reasons for using online food purchasing services. The detail of profile and purchasing behavior of Generation $\mathrm{Z}$ consumer of Gofood and GrabFood is presented in Table 1.

Table 1 shows that the majority of Generation $\mathrm{Z}$ consumers who use online food ordering services (both Gofood and GrabFood) are female with a total of 53 consumer or 53\% of all respondent, while the rest 47 people or $47 \%$ are male. Previous research has shown that the majority of consumers of food online services are well-educated women with good income levels [22].

Furthermore, based on monthly income aspect, this study found that the majority of Generation Z consumers (57\%) has an monthly income between IDR 1,000,000 and IDR.1,9999,999. Since the respondents in this study are students, the income range is quite high. As comparison, the Provincial Minimum Wage or Upah Minimum Provinsi (UMP) for the Special Region of Yogyakarta in 2021 is IDR. 1,765,000 while the Regency Minimum Wage or Upah Minimum Kabupaten (UMK) of Bantul Regency where the UMY is located there is IDR. 1,842,460 [23].

With regard to purchasing behavior on Gofood and GrabFood, this study found that heavy meal (rice, noodles, satay, etc.) was the most chosen product by Generation $\mathrm{Z}$ consumers. As many as $85 \%$ of consumers stated that they had ordered heavy meal through Gofood and GrabFood delivery service applications. While beverage products, such as thai tea, milk, juice, coffee milk, etc. and snacks (bread, martabak, seblak, macaroni, etc.) consumers chose $65 \%$ and $59 \%$ respectively.

Moreover, regarding the range of prices paid for a food product purchased through Gofood and GrabFood, the majority of Generation Z consumers $(50 \%)$ buy food products with a price range of IDR. 15,000 to IDR 25,000. Meanwhile, regarding the reasons for purchasing food products online, practical reasons and price promotions are the main reasons for consumers when buying food products through Gofood and GrabFood. Previous research on the factors that influence consumers to purchase food products through Gofood 
and GrabFood applications states that the quality of services and applications is the main factor for consumers to choose online food delivery services [24] [25].

Table 1. Generation $Z$ consumer profile and purchasing behavior $(\mathrm{N}=100)$.

\begin{tabular}{|c|c|c|c|c|}
\hline \multirow[t]{2}{*}{ No } & \multirow[t]{2}{*}{ Variable } & \multirow[t]{2}{*}{ Range } & \multicolumn{2}{|c|}{ Respondent } \\
\hline & & & Number & $\%$ \\
\hline \multirow[t]{2}{*}{1} & Gender & Male & 47 & 47 \\
\hline & & Female & 53 & 53 \\
\hline \multirow[t]{5}{*}{2} & Income (IDR/month) & $\leq 1.000 .000$ & 18 & 18 \\
\hline & & $1.000 .000-1.999 .999$ & 57 & 57 \\
\hline & & $2.000 .000-2.999 .999$ & 13 & 13 \\
\hline & & $3.000 .000-3.999 .999$ & 7 & 7 \\
\hline & & $\geq 4.000 .000$ & 5 & 5 \\
\hline \multirow[t]{5}{*}{3} & Monthly purchase frequency & 1 time & 11 & 11 \\
\hline & & 2 times & 19 & 19 \\
\hline & & 3 times & 22 & 22 \\
\hline & & 4 times & 7 & 7 \\
\hline & & $>5$ times & 41 & 41 \\
\hline \multirow[t]{3}{*}{4} & Type of food product & Heavy meal & 85 & 85 \\
\hline & & Snack & 59 & 59 \\
\hline & & Baverages & 65 & 65 \\
\hline \multirow[t]{6}{*}{5} & Price of food product (IDR) & $\leq 15.000$ & 12 & 12 \\
\hline & & $15.000-25.000$ & 50 & 50 \\
\hline & & $25.000-35.000$ & 27 & 27 \\
\hline & & $35.000-45.000$ & 7 & 7 \\
\hline & & $45.000-55.000$ & 3 & 3 \\
\hline & & $>55.000$ & 1 & 1 \\
\hline \multirow[t]{4}{*}{6} & Reason for food online service & Saving time & 47 & 27,4 \\
\hline & & Practical & 62 & 36 \\
\hline & & Promos & 57 & 33,1 \\
\hline & & Lazy Out & 6 & 3,5 \\
\hline
\end{tabular}

\subsection{Generation Z consumer attitudes on Gofood and GrabFood Service}

The attitude of Generation $\mathrm{Z}$ consumers towards Gofood and GrabFood online food delivery services is measured by assessing the level of consumer trust with the consumers' evaluations of the Gofood and Grabfood delivery service applications.

\subsubsection{Generation Z consumer trust on Gofood and GrabFood Service}

The level of consumer trust is the assessment of respondents who believe that between Gofood and Grabfood has a certain attribute. More details regarding the assessment of 
Generation Z consumer confidence in the Gofood and Grabfood delivery service applications can be seen in Table 2 .

Tabel 2. Consumer trust score of Gofood and GrabFood service.

\begin{tabular}{|l|c|c|c|c|c|c|c|}
\hline \multirow{2}{*}{ Atribut } & \multicolumn{9}{c|}{ GOFOOD } \\
\cline { 2 - 10 } & $\mathbf{1}$ & $\mathbf{2}$ & $\mathbf{3}$ & $\mathbf{4}$ & $\mathbf{5}$ & Trust Score (bi) & Category \\
\hline Practicality & 0 & 2 & 3 & 57 & 38 & 4.31 & Very Good \\
\hline Rates & 1 & 3 & 28 & 47 & 20 & 3.81 & Good \\
\hline Speed & 1 & 1 & 13 & 54 & 31 & 4.1 & Good \\
\hline Trust & 0 & 0 & 4 & 47 & 49 & 4.45 & Very Good \\
\hline Security & 0 & 0 & 9 & 54 & 37 & 4.28 & Very Good \\
\hline Promotion & 1 & 0 & 19 & 41 & 39 & 4.26 & Very Good \\
\hline \multicolumn{7}{|c|}{ Total } \\
\multicolumn{7}{|c|}{ Atribut } & \multicolumn{7}{|c|}{ GRABFOOD } & Very Good \\
\cline { 2 - 9 } & $\mathbf{1}$ & $\mathbf{2}$ & $\mathbf{3}$ & $\mathbf{4}$ & $\mathbf{5}$ & Trust Score (bi) & Category \\
\hline Practicality & 0 & 3 & 11 & 49 & 37 & 4.2 & Good \\
\hline Rates & 0 & 3 & 27 & 47 & 22 & 3.87 & Good \\
\hline Speed & 1 & 4 & 19 & 56 & 20 & 3.9 & Good \\
\hline Trust & 0 & 0 & 16 & 54 & 30 & 4.15 & Good \\
\hline Security & 0 & 0 & 17 & 57 & 26 & 4.09 & Good \\
\hline Promotion & 0 & 0 & 10 & 54 & 36 & 4.27 & Very Good \\
\hline & Total & & & Good \\
&
\end{tabular}

Table 2 shows that based on the analysis of the consumer trust, it indicates that Gofood's consumer trust value is better than GrabFood. This can be seen from the value of each attribute where Gofood has an average trust total score 25.21 which is greater than Grabfood total core of 24.48 .

Based on the achievement of the trust value of each Gofood attribute, it is also still better than GrabFood where four of the six Gofood attributes, namely practicality, trust, security and promotion, show a very good trust category with an average trust score of 4.31 for practicality attribute, 4.45 for trust, 4.28 for security and 4.26 for promotion attribute. Meanwhile, compare to GrabFood application, there is only one attribute, namely the promotion which shows very good with a trust score of 4.27 , although the other five attributes are in the good category.

The level of trust indicates the consumer's assessment of the implementation of product attributes [26]. Respondents' assessment of Gofood and GrabFood's online food ordering services is quite good since none of the attributes are considered in bad category.

\subsubsection{Generation $Z$ consumer evaluation and attitude toward Gofood and GrabFood Service}

Furthermore, to understand the attitudes of Generation $\mathrm{Z}$ consumers towards Gofood and GrabFood, it is done by multiplying the trust score with consumer evaluations of all attributes of both Gofood and GrabFood. The consumer evaluation score is a consumer's assessment of the attributes of a service or product provider after consumers consume or use the services and products as a comparison from the previously obtained trust score [27].

Consumer attitudes $\left(\mathrm{A}_{0}\right)$ are obtained by multiplying trust score $\left(\mathrm{b}_{\mathrm{i}}\right)$ and consumer evaluation value $\left(\mathrm{e}_{\mathrm{i}}\right)$ against the attributes of the Gofood and GrabFood messaging service 
applications. This figure shows the respondents' assessment of Gofood and Grabfood attributes, so a number will be obtained that shows consumer ratings of an attribute of practicality, tariffs, speed, trust, security, and promotion. More details regarding the assessment of the attitudes of Generation Z (Ao) consumers towards Gofood and Grabfood delivery service can be seen in Table 3 .

Tabel 3. Generation $\mathrm{Z}$ consumer attitudes toward Gofood and GrabFood service.

\begin{tabular}{|l|c|c|c|c|}
\hline \multirow{2}{*}{ Atribute } & \multicolumn{4}{|c|}{ GOFOOD } \\
\cline { 2 - 5 } & $\begin{array}{c}\text { Evaluation Score } \\
\left(\boldsymbol{e}_{\boldsymbol{I}}\right)\end{array}$ & $\begin{array}{c}\text { Trust Score } \\
\left(\boldsymbol{b}_{\boldsymbol{i}}\right)\end{array}$ & $\begin{array}{c}\text { Attitude Score } \\
\left(\boldsymbol{A}_{\boldsymbol{0}}\right)\end{array}$ & Category \\
\hline Practicality & 4.14 & 4.31 & 17.90 & Positive \\
\hline Rates & 4.03 & 3.81 & 15.65 & Positive \\
\hline Speed & 3.86 & 4.1 & 16.04 & Positive \\
\hline Trust & 4.11 & 4.45 & 18.37 & Positive \\
\hline Security & 4.05 & 4.28 & 17.42 & Positive \\
\hline Promotion & 3.99 & 4.26 & 16.85 & Positive \\
\hline \multicolumn{1}{|c|}{ Atribute } & \multicolumn{5}{|c|}{ GRABFOOD } \\
\cline { 2 - 5 } & Evaluation Score & Trust Score & Attitude Score & Category \\
& $\left(\boldsymbol{e}_{\boldsymbol{1}}\right)$ & $\left(\boldsymbol{b}_{\boldsymbol{i}}\right)$ & $\left(\boldsymbol{A}_{\boldsymbol{0}}\right)$ & \\
\hline Practicality & 4.14 & 4.2 & 17.39 & Positive \\
\hline Rates & 4.03 & 3.87 & 15.74 & Positive \\
\hline Speed & 3.86 & 3.9 & 15.21 & Positive \\
\hline Trust & 4.11 & 4.15 & 17.05 & Positive \\
\hline Security & 4.05 & 4.09 & 16.58 & Positive \\
\hline Promotion & 3.99 & 4.27 & 17.15 & Positive \\
\hline
\end{tabular}

Table 3 shows that in general, Gofood and GrabFood online food delivery services are considered positive by Generation Z. Furthermore, based on the result from each attribute of both application, the Gofood delivery service application attribute that shows the highest attitude value is the trust, while the attribute with the lowest value is tariff. Previous studies mentioned that Generation $\mathrm{Z}$ consumers or known as e-Generation are hyperconnected consumers who rely on trust based on reviews from previous consumers who use the same service [28].

Moreover, the Grabfood delivery service application showed different results where respondents rated the practicality attribute as the best attribute, while the speed attribute showed as the lowest score even though all atributtes were still in the positive category. Practicality is one of the main characteristics of Generation Z [29].

\subsection{Attributes of Gofood and Grabfood that are most considered by Generation $Z$ consumers}

Beside examine the attitudes of Generation Z consumers towards Gofood and GrabFood delivery service applications, this study also analyzes the Gofood and GrabFood attributes that consumers consider the most. To find out which Gofood and Grabfood attributes are most considered by Generation Z, this study uses the One Way Anova test to test whether there is a difference between the existing attributes [30] and the Fisher's Least Significant Difference [LSD] Post Hoc test to determine the most considered attributes [31]. 


\subsubsection{Attributes of Gofood that are most considered by Generation Z consumers}

Table 4 shows the results of One Way Anova test of Gofood attribute where demonstrates F-stat of 5.23 which is greater than F table of 2.23. These results can be interpreted that there are significant differences in the attitudes of respondents to the attributes of Goofood application.

Table 4. One way anova test results of Gofood application.

\begin{tabular}{|c|c|c|c|c|c|}
\hline Source of Variation & $\boldsymbol{S S}$ & $\boldsymbol{d f}$ & $\boldsymbol{M S}$ & $\boldsymbol{F}$ & $\boldsymbol{F}$ crit \\
\hline Between Groups & 542.975 & 5 & 108.595 & 5.230646 & 2.229193 \\
\hline Within Groups & 1233.21 & 594 & 20.7613 & & \\
\hline Total & 1287.19 & 599 & & & \\
\hline
\end{tabular}

Furthermore, to find out the most considered attributes on Gofood application, the Fisher's Least Significant Difference [LSD] Post Hoc test was carried out. The results of the Post Hoc LSD test are presented in Table 5.

Table 5. Post hoc analysis test results Gofood delivery service application.

\begin{tabular}{|c|c|}
\hline Atribute & Average Value \\
\hline Practicality & $17.90 \mathrm{~b}$ \\
\hline Rates & $15.65 \mathrm{c}$ \\
\hline Speed & $16.14 \mathrm{c}$ \\
\hline Trust & $18.37 \mathrm{a}$ \\
\hline Security & $17.42 \mathrm{~b}$ \\
\hline Promotion & $16.85 \mathrm{c}$ \\
\hline
\end{tabular}

Post Hoc analysis as presented in Table 5 shows that the Gofood attribute that is most considered by Generation $\mathrm{Z}$ consumers in this study is trust as it shows the highest average value of 18.37. Trust is an important factor in electronic transactions that have risks because there is no direct contact [32] especially for Generation Z, which is an interconnected generation that relies on trust which is usually obtained from peer or product reviews on the internet [33].

\subsubsection{Attributes of GrabFood that are most considered by Generation Z consumers}

Table 6 show the results of Anova One Way analysis which presented the calculated F-stat. Of 3.98 which is greater than $\mathrm{F}$ table 2.23. This result shows that there are significant differences in the attitudes of respondents to the attributes of GrabFood delivery service application.

Table 6. One way anova test results on the GrabFood application.

\begin{tabular}{|c|c|c|c|c|c|}
\hline Source of Variation & $\boldsymbol{S S}$ & $\boldsymbol{d f}$ & $\boldsymbol{M S}$ & $\boldsymbol{F}$ & $\boldsymbol{F}$ crit \\
\hline Between Groups & 376.28 & 5 & 75.256 & 3.975114 & 2.229193 \\
\hline Within Groups & 11245.48 & 594 & 18.93178 & & \\
\hline Total & 11621.76 & 599 & & & \\
\hline
\end{tabular}

Furthermore, the Fisher's Least Significant Difference [LSD] Post Hoc test was carried out to find out the most considered attributes in GrabFood application. The results of the Post Hoc LSD test are presented in Table 7. 
Table 7. Post hoc analysis test results GrabFood delivery service application.

\begin{tabular}{|c|c|}
\hline Atribute & Average Value \\
\hline Practicality & $17.39 \mathrm{a}$ \\
\hline Rates & $15.74 \mathrm{c}$ \\
\hline Speed & $15.21 \mathrm{c}$ \\
\hline Trust & $17.05 \mathrm{a}$ \\
\hline Security & $16.58 \mathrm{~b}$ \\
\hline Promotion & $17.15 \mathrm{a}$ \\
\hline
\end{tabular}

Based on the LSD test, it is known that the most considered attribute by GrabFood consumers is practicality. Respondents considered that GrabFood application was practical and easy to use. Generation $Z$ is a generation that is heavily influenced by digital technology that provides convenience in everything, therefore the practicality factor is their main factor in choosing products and services [34].

\section{Conclusions}

The majority of Generation $\mathrm{Z}$ consumers who order food online through the Gofood and GrabFood applications are women with a monthly income of between IDR. 1,000,000 and IDR. 1,999,999 and an average purchase of more than five times per month. Heavy meal is the most widely purchased type of food and food price range that consumers buy the most is between IDR. 15,000 and IDR. 25,000 with promotion as the main reason for using Gofood and GrabFood services.

Furthermore, regarding consumer preferences, this study concludes that the Gofood delivery service is preferred over the GrabFood application by Generation Z. The most considered attribute by respondents in using Gofood application is trust, while the attribute in GrabFood application that is most considered is practicality.

\section{References}

1. B. K. Pathak and S. Bend, Issues Inf. Syst. 21, 306 (2020).

2. Kuruwitaarachchi, M. S. A. Yajid, A. Khatibi, and S. M. F. Azam, Int. J. e-Education, eBusiness, e-Management e-Learning 10, 95 (2020).

3. Techinasia, Ecommerce (2021).

4. H. Akhmadi, S. Susanawati, N. Putri Utami, and A. S. Widodo, Journal of Information and Organizational Sciences. 45, 95 (2021).

5. Momentum Works, Food Delivery Platforms in Southeast Asia (SEA) (2021).

6. Katadata, (2019).

7. D. Setyowati, Katadata.Co.Id (2021).

8. A. M. Prabhash, EPRA Int. J. Multidiscip. Res. (IJMR)-Peer Rev. J. 6, 96 (2020).

9. Z. R. Hinduan, A. Anggraeni, and M. I. Agia, in New Gener. Z Asia Dyn. Differ. Digit., edited by E. Gentina and E. Parry (Emerald Publishing Limited, 2020), pp. 121-134.

10. E. Simangunsong, Mix J. Ilm. Manaj. 8, 243 (2018).

11. A. Prasasti, F. I. Aulisaina, and M. A. Rahman Hakim, The Winners 22, 57 (2021).

12. T. Wijaya, A. Darmawati, and A. M. Kuncoro, Int. J. Adv. Comput. Sci. Appl. 11, 27 (2020). 
13. P. Chaturvedi, K. Kulshreshtha, and V. Tripathi, Young Consum. 21, 403 (2020).

14. D.-C. Dabija and L. Lung, 1 (2019).

15. C. Walker, Child. Geogr. 19, 267 (2021).

16. APJII, Penetrasi \& Profil Perilaku Pengguna Internet Indonesia 2018 (Jakarta, Indonesia, 2018).

17. Statisticts Indonesia, Berita Resmi Statistik Hasil Sensus Penduduk 2020: Komposisi Penduduk Indonesia (Jakarta, Indonesia, 2021).

18. R. Lestari and G. Genoveva, in Int. Conf. Univ. Pekalongan 2021 (2021), pp. 65-74.

19. A. V. Santoso, J. Strateg. Pemasar. 7, 1 (2020).

20. M. Razak, M. Hidayat, and M. H. Rahman, AkMen 18, 84 (2021).

21. H. Akhmadi and S. Pratolo, in International Conference on Agribusiness and Rural Development. (IConARD 2020) (2021), p. 02015.

22. A. Dominici, F. Boncinelli, F. Gerini, and E. Marone, J. Retail. Consum. Serv. 60, 102473 (2021).

23. Special Region of Yogyakarta Regional Government, Gov. Off. DIY (2020).

24. M. Puspita and A. Aprilia, J. Manaj. Perhotelan 6, 88 (2020).

25. Nurliza, A. Suharyani, and A. Nugraha, AGRARIS: Journal of Agribusiness and Rural Development Research. 7, 1 (2021).

26. N. Qomariyah, I. Santoso, and M. Effendi, J. Ind. 3, 53 (2014).

27. P. A. Harsita and A. Amam, Agrisocionomics J. Sos. Ekon. Pertan. 3, 19 (2019).

28. S. Tabassum, M. G. Khwaja, and U. Zaman, Inf. 11, 1 (2020).

29. M. T. A. Jima'ain, W. A. R. W. I. Fik, and A. M. Alias, Muhammad Ikram Mohamad, JETAL J. English Teach. Appl. Linguist. 2, 37 (2020).

30. D. K. Choudhury and U. Gulati, Decision 47, 49 (2020).

31. A. N. H. Nguyen, T. E. Johnson, D. W. Jeffery, D. L. Capone, L. Danner, and S. E. P. Bastian, Foods 9, 1 (2020).

32. A. B. Reddy and P. Jagadeesan, Int. J. Adv. Sci. Technol. 29, 2117 (2020).

33. J. Vieira, R. Frade, R. Ascenso, I. Prates, and F. Martinho, Adm. Sci. 10, 103 (2020).

34. J. Park and J. Chun, Humanit. Soc. Sci. Commun. 7, 1 (2020). 